\title{
Influence of Local Tetracycline on the Microbiota of Alveolar Osteitis in Rats
}

\author{
Joseane Maria Dias BOSCO ${ }^{1}$ \\ Sérgio Ricardo de OLIVEIRA ${ }^{1}$ \\ Álvaro Francisco BOSCO ${ }^{1}$ \\ Christiane Marie SCHWEITZER ${ }^{2}$ \\ Elerson Gaetti JARDIM JÚNIOR ${ }^{3}$ \\ ${ }^{1}$ Department of Surgery and Integrated Clinic, Dental School of Araçatuba, \\ São Paulo State University, Araçatuba, SP, Brazil \\ ${ }^{2}$ Department of Computer Science, Karlstad University, Sweden; and Center of Mathematics, \\ Computer and Cognition, Federal University of ABC, Santo André, SP, Brazil \\ ${ }^{3}$ Department of Pathology and Clinical Propedeutics, Dental School of Araçatuba, \\ São Paulo State University, Araçatuba, SP, Brazil
}

\begin{abstract}
The aim of the present study was to evaluate the effects of local tetracycline on the occurrence of alveolar osteitis in rats, and on the microbiota associated to this infection. Forty Wistar rats were randomly assigned to 4 groups $(n=10)$ : I - the rats had the maxillary right incisor extracted and the alveolar wound did not receive any treatment; II - adrenaline and Ringer-PRAS were introduced into the alveolar wound; III - the alveolar wound was irrigated with sterile saline; and IV - the alveolar wound was irrigated with an aqueous solution of tetracycline. Microbial samples from the alveolar wounds were collected 2 days after surgery and inoculated on blood agar (with and without $8 \mu \mathrm{g} / \mathrm{mL}$ of tetracycline) and other selective media, and were incubated in either aerobiosis or anaerobiosis at $37^{\circ} \mathrm{C}$, for 2 to 14 days. It was verified that tetracycline reduced the occurrence of alveolar osteitis in the rats and caused significant changes in the microbiota of the surgical sites, decreasing the number of anaerobes and increasing the participation of tetracycline-resistant and multi-resistant microorganisms.
\end{abstract}

Key Words: tetracycline, alveolar osteitis, dry alveolus, microorganisms, antimicrobials.

\section{INTRODUCTION}

Alveolar osteitis remains one of the most common postoperative complications after dental extractions and it is a good model to study bone infections in the oral cavity. The development of alveolar osteitis is a multifactorial event and an active role of microorganisms has been suggested, starting the chain of fibrinolysis (1). This theory is confirmed since the treatment of alveolar osteitis with antibiotics leads to improvement of clinical outcome. Infection of the surgical site is therefore not simply a secondary event, but can rather be relevant to the pathogenesis of this clinical condition. In spite of this, several dentists believe that the ordinary use of systemic antibiotics with the sole purpose of reduc- ing the incidence of alveolar osteitis, even if effective, is not justified due to the selection of bacterial strains resistant to antibiotics and to the possible systemic side effects (1).

However, tetracycline has been extensively used in dentistry, especially as an adjunctive to treatment of periodontal diseases and other infections (2) and should be tested to verify its ability to avoid opportunistic infections in dental surgery, when predisposing conditions are present. Since the use of antimicrobials frequently collaborate with the increase of the antimicrobial resistance of normal microbiota (3), the administration of tetracycline as a topic or systemic drug could increase the resistance to this drug and to other drugs currently employed in dentistry and medicine, due to the 
presence of plasmids associated to resistance to antimicrobials, which commonly harbor more than one single resistance gene (4).

The present study evaluated the effects of local tetracycline on the occurrence of alveolar osteitis in rats under experimental conditions favorable to establishment of this pathology, and on the microbiota associated to this infection, especially regrding the microbial patterns of resistance to antimicrobial drugs.

\section{MATERIAL AND METHODS}

\section{Experimental Groups}

This study has been independently reviewed and approved by the Research Ethics Committee of the Dental School of Araçatuba, São Paulo State University, Brazil. Forty male Wistar rats (Rattus norvegicus) weighing approximately $200 \mathrm{~g}$ were randomly assigned to 4 groups $(n=10)$. In group $I$, the maxillary right incisor was extracted and hemostasis was done by compression. In group II, the same procedures were done and a sterile paper point soaked in adrenaline (1:1000) was introduced into the alveolar wound for 1 min. After that, $0.1 \mathrm{~mL}$ of Ringer-PRAS was flushed into the alveolus to create redox conditions similar to those observed in human alveolar osteitis. In group III, the same procedures as those of group II were done up to application of adrenaline. Thereafter, the alveolar wound was filled with $3 \mathrm{~mL}$ of saline for $30 \mathrm{~s}$ and, immediately after that, $0.1 \mathrm{~mL}$ of Ringer-PRAS was flushed into the wound. In group IV, the same procedures as those of group III were done, except for the fact that the solution used for irrigation was tetracycline-HCl 100 mg/mL (Teuto, São Paulo, SP, Brazil) sterilized by filtration. In all groups, the procedures were performed under general anesthesia of the animals with sodium thiopental $(50 \mathrm{mg} / \mathrm{kg})$.

All animals were evaluated daily and the severity of the infection was registered according to the following categories: (-) absence of clinical signs of alveolar osteitis; (+) alveolus with little amount of purulent secretion; $(++)$ moderate amount of purulent secretion; $(+++)$ purulent secretion obliterating the entrance of the alveolus; $(++++)$ abundant purulent secretion accompanied by tissue swelling.

On the 2nd postsurgical day, samples were collected from the alveolar wounds of all animals and transferred to $4 \mathrm{~mL}$ of VMGA III (viability preserving medium no. III; University of Gothenburg, Sweden), diluted in VMG I, and aliquots were inoculated on fastidious anaerobe agar supplemented with horse blood (5\%), with and without tetracycline $(8 \mu \mathrm{g} / \mathrm{mL}), \mathrm{CVE}$ agar, BBE agar (Difco, Detroit, MI, USA), CFAT agar, MacConkey agar (Difco) and Sabouraud-Dextrose agar (Difco), and incubated in either aerobiosis or anaerobiosis $\left(85 \% \mathrm{~N}_{2}, 10 \% \mathrm{CO}_{2}, 5 \% \mathrm{H}_{2}\right)$ at $37^{\circ} \mathrm{C}$ for 2 to 14 days.

Colonies on plates with and without tetracycline were counted to determine the percentage of resistant microorganisms in each sample (2). The isolated microorganisms were identified by analysis of morphocellularmorphocolonial characteristics and by Rapid ID 32A, API Staph, Rapid ID 32Strep, API 20 Strep (BioMérieux, Marcy l'Etoile, Rhone Department, France) and RapIDANA II kits (Innovative Diagnostic Systems Inc., Peterson Place Norcross, GA, USA).

\section{Antimicrobial Susceptibility Tests of the Isolates}

Susceptibility tests was performed by the agar dilution method. The drugs employed were amoxicillin, amoxicillin/clavulanic acid, penicillin G, cefoxitin, clindamycin, erythromycin, imipenem, lincomycin, metronidazole and tetracycline. The NCCLS (National Committee for Clinical Laboratory Standards) breakpoints to the drugs were followed. Wilkins-Chalgren agar supplemented with horse blood (5\%), hemin $(0.5$ $\mu \mathrm{g} / \mathrm{mL})$ and menadione $(0.1 \mu \mathrm{g} / \mathrm{mL})$ was used for anaerobes and Mueller-Hinton agar was used for facultative anaerobes.

A total of 244 bacterial strains cultivated from the plates without tetracycline were randomly chosen and used throughout the susceptibility testing, divided as follows: Actinomyces sp. and other actinomycetes, 24; Bacteroides sp., 11; B. fragilis group, 18; Clostridium sp., 3; Enterococcus spp., 11; Eubacterium spp., 18; Fusobacterium sp., 12; F. nucleatum, 18; other fusobacteria, 13; Lactobacillus sp., 6; Micromonas micros, 2; Peptostreptococcus spp., 14; Porphyromonas sp., 8; Prevotella sp., 9; P. intermedia-nigrescens, 7; enteric Gram-negative facultative rods, 19; Selenomonas sp., 9; Staphylococcus epidermidis, 3; Streptococcus spp., 20; and Veillonella sp., 12.

The bacterial inoculum was standardized to achieve $10^{5}$ cells/spot. F. nucleatum ATCC 10953, E. lentum ATCC 43055, B. fragilis ATCC 23745, E. coli 
ATCC 25922 and S. aureus ATCC 29213 were used as reference strains for quality control of susceptibility tests. Plates were incubated in anaerobiosis or aerobiosis at $37^{\circ} \mathrm{C}$ for $48 \mathrm{~h}$.

\section{Statistical Analysis}

Bioestat 2.0 statistical software was used for all statistical analyses. The percentage of antibiotic-resistant isolates was computed by averaging these values within each experimental animal and then within each group. Significance in these microbiological parameters among groups was analyzed statistically by the KruskalWallis test. Significance level was set at $5 \%$.

\section{RESULTS}

The rats in group II presented a more intense alveolar osteitis followed by group III. In group IV, this pathology was present in only $40 \%$ of the animals and much more mild clinical signs were found. Alveolar osteitis was not observed group I (control).

The absolute number of microorganisms recovered from the groups showed significant variation. Regarding obligate and facultative anaerobes, groups I, II and III were statistically similar to each other ( $p>0.05)$, but differed significantly from group IV $(\mathrm{p}=0.01)$. It was possible to verify the presence of microorganisms resistant to tetracycline in all groups, varying from $4.5 \%$ $(4.5 \pm 1.3$, group I) to $23.58 \%(23.58 \pm 3.7$, group IV $)$.

There was no statistically significant difference $(\mathrm{p}<0.05)$ among groups I, II and III regarding the percentage of tetracycline-resistant isolates, but these groups were significantly different from group IV $(\mathrm{p}=0.01)$. Microorganisms resistant to tetracycline represented $4.5 \%, 6.87 \%, 4.3 \%$ and $23.58 \%$ of the

Table 1. Participation of obligated anaerobes, facultative anaerobes, Gram-positive and Gram-negative microorganisms in the experimental groups.

\begin{tabular}{lcccc}
\hline & $\begin{array}{c}\text { Obligate } \\
\text { Anaerobes }\end{array}$ & $\begin{array}{c}\text { Facultative } \\
\text { Anaerobes }\end{array}$ & $\begin{array}{c}\text { Gram }+ \\
\text { m.os. }\end{array}$ & $\begin{array}{c}\text { Gram - } \\
\text { m.os }\end{array}$ \\
\hline Group I & 83.44 & 16.56 & 43.21 & 56.79 \\
Group II & 86.33 & 13.67 & 39.75 & 60.25 \\
Group III & 92.17 & 7.83 & 41.13 & 58.87 \\
Group IV & 62.87 & 37.13 & 71.29 & 28.71 \\
\hline
\end{tabular}

isolated microflora from groups I, II, III and IV, respectively, with statistically significant difference $(p<0.05)$ between group IV and the other experimental groups.

The participation of obligate anaerobes, facultative anaerobes, Gram-positive and Gram-negative bacteria is presented in Table 1. A predominance of anaerobes was noted in all groups, even though in the group treated with tetracycline (group IV) the percentage of these microorganisms was significantly lower $(p=0.01)$. In this group, there was an inversion of the participation of Gram-positive bacteria, whereas in the other experimental groups the participation of Gramnegative bacteria seemed more relevant $(\mathrm{p}=0.01)$. The use of tetracycline for alveolar wound irrigation produced a more accentuated decrease in the number of Gramnegative anaerobic rods, but without a significant improvement in the populations of enterobacteria. Fungi were not isolated from any sample.

Table 2 presents the resistance of the selected microorganisms to the antimicrobials. The vast majority of resistant bacteria showed multiple resistant profile, involving resistance to $\beta$-lactams, macrolides, lincosamides and tetracycline. The levels of drug resistance to imipenem, cefoxitin and metronidazole were not changed by the use of tetracycline- $\mathrm{HCl}$ solution, but multi-resistant bacteria were more frequently found in the group treated with tetracycline.

Table 2. Resistance to antimicrobial drugs (\%) of 244 isolates recovered from the alveolar wounds of rats.

\begin{tabular}{lrrrr}
\hline $\begin{array}{l}\text { Antimicrobial } \\
\text { drug }\end{array}$ & $\begin{array}{c}\text { Group I } \\
(\mathrm{n}=60)\end{array}$ & $\begin{array}{r}\text { Group II } \\
(\mathrm{n}=60)\end{array}$ & $\begin{array}{c}\text { Group III } \\
(\mathrm{n}=62)\end{array}$ & $\begin{array}{c}\text { Group IV } \\
(\mathrm{n}=62)\end{array}$ \\
\hline Amoxicillin & 6.67 & 10.00 & 9.68 & 20.97 \\
Amoxicillin/Clav. acid & 3.33 & 0.00 & 3.23 & 8.06 \\
Cefoxitin & 6.67 & 10.00 & 6.45 & 12.90 \\
Clindamycin & 13.33 & 10.00 & 8.06 & 11.29 \\
Erythromycin & 28.33 & 21.67 & 24.19 & 32.25 \\
Imipenem & 3.33 & 1.67 & 1.61 & 0.00 \\
Lincomycin & 13.33 & 13.33 & 8.06 & 11.29 \\
Metronidazole & 25.00 & 20.00 & 37.10 & 43.55 \\
Penicillin & 18.33 & 20.00 & 14.52 & 24.19 \\
Tetracycline & 15.00 & 13.33 & 11.29 & 33.87 \\
\hline
\end{tabular}

Breakpoints used ( $\mu \mathrm{g} / \mathrm{mL})$ : Amx, 16; Amx/clav. acid, 16/8; Cx, 32; Cl, 4; Er, 16; Im, 8; Li, 16; Mz, 16; Pe, 16; Te, 8. 


\section{DISCUSSION}

The microflora recovered from the experimental groups was predominantly anaerobic, and was very similar to the one associated with gingivitis in rats. However, some facultative anaerobes, especially enteric ones, represented $8 \%$ of the cultivable microbiota. The occurrence of Bacteroides fragilis group and Enterobacteriaceae is relatively frequent in the oral cavities of rats.

Tetracycline is one of the most commonly used antimicrobial in periodontal therapy, and its local administration has been extensively evaluated, with satisfactory improvement of clinical parameters, in addition to non-antibacterial properties that include enhanced adhesion of fibroblast cells (5) and reduced proteolysis by anaerobes (6) or leukocytes (5). However, the use of tetracycline should not be stimulated as a routine procedure based on the findings of the present investigation. The main goal of this study was to evaluate the real capacity of this drug to prevent or at least reduce the risk of infections in bone tissues when the clinical conditions are really favorable to the establishment of an infectious process.

Two major findings were noted in this study. Firstly, alveolar osteitis was present in only part of the animals treated with local tetracycline, whereas in groups II and III this pathology was observed in all rats. Even when alveolar osteitis was present, it had a mild intensity. Secondly, a high level of antibiotic resistance could be found in the microorganisms recovered from all experimental groups, but this occurrence was more prominent in the treated group. The group treated with tetracycline presented higher levels of facultative anaerobes, which show a natural resistance to metronidazole and a very limited susceptibility to macrolides, tetracycline (7-8) and to $\beta$-lactams (9).

In addition to the effects on host tissues, tetracycline has a unique property of attachment to mineralized tissues, creating a reservoir of antimicrobial activity that is not easily cleared out by saliva or tissue exudates (10). In spite of its favorable properties, this drug has been associated to an increase in the antimicrobial resistance in oral bacteria (10-11), especially between members of genus Veillonella and facultative Grampositive anaerobes (12). However, this phenomenon of selection of microorganisms is very common in pathogenic bacteria, not only related to tetracycline (13) or oral bacteria, since it has been detected in microbial communities in soil, water (14) and indigenous microflora from animals (4).

Although Lancaster et al. (12) have shown an increase in the resistance to tetracycline among Gramnegative anaerobes, most tetracycline-resistant isolates were Peptostreptococcus spp., Streptococcus spp., Enterococcus spp. or Enterobacteriaceae, as reported elsewhere $(15,16)$. Gram-negative anaerobes, on the other hand, were sensitive to the drug, as also observed by Lakhssassi et al. (17). Except for the B. fragilis group and Bacteroides sp., which showed $27.78 \%$ and $36.37 \%$ of isolates resistant to tetracycline, respectively, no noteworthy resistant Gram-negative anaerobe isolate was found.

The resistance to $\beta$-lactams, lincosamides, macrolides and other antimicrobial drugs, in group IV was significantly higher, but not all resistant bacteria showed concomitant resistance to tetracycline, as previous reported for tetracycline derivatives (18). This phenomenon must be further investigated before the indication of this drug as a co-adjuvant in oral surgery. Data must be reevaluated since most tetracycline resistant microorganisms belonged to genera and species commonly associated to opportunistic infections in humans. This event could be likely to occur in human patients since the levels of resistance to tetracycline observed in the present study (group IV) were very similar to those reported in previous studies $(19,20)$ for isolates of viridans streptococci, which are opportunistic microorganisms commonly inhibited by $\beta$-lactams (20).

In conclusion, although the topical use of tetracycline solution in rat alveolar wounds reduced the occurrence of alveolar osteitis, it also caused significant changes in the microbiota, decreasing the number of anaerobes and increasing the participation of tetracycline-resistant and multi-resistant microorganisms.

\section{RESUMO}

O objetivo do presente estudo foi avaliar os efeitos do uso tópico de tetraciclina sobre a ocorrência de alveolite em ratos e sobre a microbiota a ela associada. Quarenta ratos foram divididos, ao acaso, em 4 grupos $(n=10)$ : grupo I, realizou-se somente a extração do incisivo superior direito e a ferida alveolar não recebeu nenhum tratamento; grupo II, além da extração dental, soluções de adrenalina e Ringer-PRAS foram introduzidas no interior do alvéolo; grupo III, a ferida alveolar foi irrigada com solução salina estéril; grupo IV, a ferida alveolar foi irrigada com solução aquosa de cloridrato de tetraciclina a $10 \%$. As amostras dos 
alvéolos para processamento microbiológico foram coletadas dois dias após a realização das cirurgias e foram inoculadas em ágar sangue com ou sem $8 \mu \mathrm{g} / \mathrm{mL}$ de tetraciclina e em outros meios de cultura seletivos, incubadas em aerobiose ou anaerobiose, a $37^{\circ} \mathrm{C}$, de 2 a 14 dias. Verificou-se que a tetraciclina reduziu a ocorrência de alveolite e provocou uma modificação significativa na microbiota do sítio cirúrgico, levando a uma redução nas proporções ocupadas pelos microrganismos anaeróbios e uma elevação da participação de microrganismos resistentes à tetraciclina e outros antimicrobianos.

\section{ACKNOWLEDGEMENTS}

The authors thank Mr. Marcelo Tramarim and Mrs. Elaine Cristina Francischini Ferreira for their technical support. This study was supported by The São Paulo State Research Foundation (FAPESP) (Processes \#01/07118-0 and 03/12763-7).

\section{REFERENCES}

1. Blum IR. Contemporary views on dry alveolus (alveolar osteitis): a clinical appraisal of standardization, etiopathogenesis and management: a critical review. Int J Oral Surg 2002;31:309-317.

2. Rodrigues RM, Gonçalves C, Souto R. Antibiotic resistance profile of the subgingival microbiota following systemic or local tetracycline therapy. J Clin Periodontol 2004;31:420427.

3. Alekshun MN, Stuart BL. Molecular mechanisms of antibacterial multidrug resistance. Cell 2007;128:1137-1150.

4. Garofalo C, Vignaroli C, Zandri G, Aquilanti L, Bordoni D, Osimani A et al.. Direct detection of antibiotic resistance genes in specimens of chicken and pork meat. Int J Food Microbiol 2007;113:75-83.

5. Roberts MC. Antibiotic toxicity, interactions and resistance development. Periodontol 2000 2002;28:280-297.

6. Grenier D, Roy E, Mayrand D. Modulation of Porphyromonas gingivalis proteinase activity by suboptimal doses of antimicrobial agents. J Periodontol 2003;74:1316-1319.

7. Sweeney LC, Dave J, Chambers PA. Antibiotic resistance in general dental practice-a cause for concern? J Antimicrob Chemother 2004;53:567-576.

8. Gaetti-Jardim-Jr E, Gaetti-Jardim EC, Lins AS, Oliveira SR, Semenoff-Segundo A. Susceptibility of anaerobic bacteria isolated from periimplantar and periodontal infections to metronidazole, lincosamines, macrolides and tetracyclines.
Rev Odonto Cienc 2007;22:131-137.

9. Frei CR, Burgess DS. Continuous infusion of $\beta$-lactams for intensive care unit pulmonary infections. Clin Microbiol Infect 2005;11:418-421.

10. Buchmann R, Müller RF, Van Dyke TE, Lange DE. Change of antibiotic susceptibility following periodontal therapy. A pilot study in aggressive periodontal disease. J Clin Periodontol 2003;30:222-229.

11. Villedieu A, Diaz-Torres ML, Hunt N, McNab R, Spratt DA, Wilson $M$ et al.. Prevalence of tetracycline resistance genes in oral bacteria. Antimicrob Agents Chemother 2003;47:878882.

12. Lancaster H, Ready D, Mullany P, Spratt D, Bedi R, Wilson M. Prevalence and identification of tetracycline-resistant oral bacteria in children not receiving antibiotic therapy. FEMS Microbiol Lett 2003;228:99-104.

13. Al-Haroni MH, Skaug N, Al-Hebshi NN. Prevalence of subgingival bacteria resistant to aminopenicillins and metronidazole in dental patients from Yemen and Norway. Int $\mathbf{J}$ Antimicrob Agents 2006;27:217-223.

14. Thompson SA, Maani EV, Lindell AH, King CJ, McArthur JV. Novel tetracycline resistance determinant isolated from an environmental strain of Serratia marcescens. Appl Environ Microbiol 2007;73:2199-2206.

15. Roberts M, Hillier S. Genetic basis of tetracycline resistance in urogenital bacteria. Antimicrob Agents Chemother 1990;34:261-264.

16. Dahlén G, Samuelsson W, Molander A. Identification and antimicrobial susceptibility of enterococci isolated from the root canal. Oral Microbiol Immunol 2000;15:309-312.

17. Lakhssassi N, Elhajoui N, Lodter JP. Antimicrobial susceptibility variation of 50 anaerobic periopathogens in aggressive periodontitis: an interindividual variability study. Oral Microbiol Immunol 2005;20:244-252.

18. Kuriyama T, Williams DW, Yanagisawa M, Iwahara K, Shimizu C, Nakagawa K et al.. Antimicrobial susceptibility of 800 anaerobic isolates from patients with dentoalveolar infection to 13 oral antibiotics. Oral Microbiol Immunol 2007;22:285-288.

19. Doern GV, Ferraro MJ, Brueggemann AB. Emergence oh high rates of antimicrobial resistance among viridans group streptococci in the United States. Antimicrob Agents Chemother 1996;40:891-894.

20. Moet GJ, Dowzicky MJ, Jones RN. Tigecycline (GAR-936) activity against Streptococcus gallolyticus (bovis) and viridans group streptococci. Diag Microbiol Infect Dis 2007;57:333336.

Accepted August 30, 2007 